\title{
Results of Development and Application of an Objective Structured Clinical Examination: A Pioneering Experience in Pharmaceutical Care
}

\author{
Maria Jose Zarzuelo', Maria Isabel Valverde-Merino,,*, Maria Fernandez-Rodriguez', \\ Noelia Amador-Fernandez ${ }^{1}$, Alberto Uribe-Sanchez ${ }^{1}$, Manuel Gomez-Guzman², \\ Fernando Martinez-Martinez ${ }^{1}$
}

1Pharmaceutical Care Research Group CTS-131, Faculty of Pharmacy, University of Granada, SPAIN. ${ }^{2}$ Department of Pharmacology, Faculty of Pharmacy, University of Granada, SPAIN.

\begin{abstract}
Objectives: Objective Structured Clinical Examination (OSCE) is a tool to assess skills and competencies and it can be relevant in Pharmacy studies and more specifically in Pharmaceutical Care (PC) to develop more practical and useful skills in the working life of a healthcare professional. Design and Methods: A prospective study was performed by students of the subject of PC in the Bachelor of Pharmacy and by students from the Master in PC, at the end of their classes. Five stations with standardized patients and written records were designed. A checklist was prepared in each station with various components to evaluate competencies and a questionnaire to explore students 'opinion was designed. Results: The mean of the global punctuation was $65.17 \pm 11.30 / 100$, being higher for the Master student than Bachelor. $85.10 \%$ of students passed the exam. The best scored station by the students was the one of "Adherence" and the worst were both the written stations ("Dispensing Record" and "Medication Review Follow-up"). The best competency was technique. The activity was valued very positively according to the global score of the opinion questionnaire $(4.50 \pm 0.50 / 5)$. Conclusion: Pharmacists must boost their skills and abilities required to perform pharmacy services. The use of OSCE represents a new tool to encourage and evaluate these PC skills.
\end{abstract}

Key words: Competencies, Education, Objective Structured Clinical Evaluation, Pharmaceutical care, Pharmacy services.

\section{INTRODUCTION}

Pharmaceutical Care (PC) is defined as the contribution of the pharmacists to the care of subjects with the aim of optimizing drug use and to improve health outcomes. ${ }^{1}$ Dispensing drugs is not the only pharmacist-led service, they can give counseling on medicines, provide solutions to issues related with drugs and improve the patient's lack of compliance, among other activities such as Medication Review with Follow-up $(\mathrm{MRF})^{2}$ and therapeutic adherence or chronic disease management, all of them are part of PC. ${ }^{3}$

Systematic reviews and meta-analysis are being published proving or attempting to prove the clinical, economic and humanistic impact of these interventions. ${ }^{4}$ However, implementation in the day-to-day work is not very common in some regions. ${ }^{5}$ In some territories of the European Union, the pharmaceutical duties are progressively changing towards a patientcentered care, ${ }^{6}$ considering the patient a priority rather than the drugs. But most training merely consists of lectures and the development of additional skills is rarely backed by standardized training/testing tools. Therefore, getting a postgraduate degree would be very useful to gain a comprehensive professional education. Traditional methods of assessment of competencies of pharmacist students are
Submission Date: 20-05-2020; Revision Date: 09-10-2020; Accepted Date: 13-03-2021

DOI: 10.5530/ijper.55.2.102 Correspondence: Ms. Valverde-Merino Pharmaceutical Care Research Group CTS131, Campus de Cartuja sn, Faculty of Pharmacy, University of Granada, SPAIN.

Phone no: +34958241931 Email id:

misabelvalverdemerino@ gmail.com

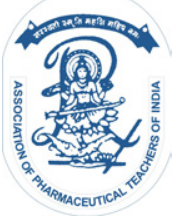

www.ijper.org 
tests, short and long questions and oral examinations. With the evolving role of the profession, Additional skills should be gained by the pharmacists to be able to perform their novel PC duties.

The European Higher Education Area (EHEA) has implemented modification in Spanish health education. The gradual conversion of teaching methodologies, focused on students' learning, is a recycling process which is essential for the proper education for the future professional. ${ }^{7}$ The education of pharmacist students is changing drastically because it is developing into a more patient-oriented profession, focusing mainly on problem-based teaching. ${ }^{8,9}$ The use of valid and reliable instruments to assess these skills, essentially ensure the quality of new professionals. Health professionals have used Objective Structured Clinical Examinations (OSCE) widely to assess competencies since 1970s. ${ }^{10}$ There are designs and validation studies about most commonly used clinical skills assessment instruments in the OSCE. ${ }^{11}$ In addition, OSCEs can be used to teach pharmacists to sort out situations in real life and to assess other competencies like: communication, correct use of techniques or prevention. ${ }^{12}$ OSCEs are part of the examinations in undergraduate and postgraduate degrees ${ }^{13}$ and are performed with standardized patients, with the aim of demonstrate specific skills in a simulated and controlled clinical situation, which are reflected on a checklist. ${ }^{14}$

OSCEs is a meaningful tool used as a part of a wider medical and nursing curriculum to train competent health professional graduates. ${ }^{15}$ They direct learning by reporting important, genuine learning needs and offer an scenario for appropriate formative feedback. ${ }^{16}$ The OSCE has been described as a strong tool to evaluate competencies in healthcare professionals. ${ }^{17}$ The efficacy of the OSCE in evaluating the implementation of knowledge and the clinical skills has been previously reported. ${ }^{17-19}$ OSCEs are more objective than evaluations based on competencies in clinical practice. As evaluation tools, OSCEs are considered valid and reliable; in addition, these tools boost motivation of students to learn. ${ }^{14}$

The aim of this project is to assess an OSCE about Pharmaceutical Care in Pharmacy Degree and Master of Pharmaceutical Care students.

\section{MATERIALS AND METHODS}

\section{Plan and recruitment}

This study was a prospective educational research that was part of an Innovative Teaching-learning Project, conducted from October 2018 until October 2019 in the Faculty of Pharmacy. From January 2019 to May 2019, an invitation in class describing the learning aims of the Project, training, duration and place, was carried out by students of the subject of PC in Pharmacy Bachelor (after the traditional exam) and by students from the Master in PC, at the end of their classes.

\section{Ethics Approval}

This study was approved as an Advanced Teaching Innovation Project by the Quality, Innovation and Prospective Unit of the University of Granada, within the call of 2018-2020 FIDO Plan, being FMM Coordinator and MJZR and MIVM members of the participant team.

\section{Clinical cases for OSCE}

A 12-member Coordinating Committee from different subjects of Pharmacy Degree was created to develop and review the OSCE cases and checklists. It was selected the most important services in PC to design the different stations. All members worked in pair and wrote a separate case and a detailed script with specific answers related to each case to allow for a reliable assessment. The standard OSCE evaluative instrument consists of a checklist for each station which included 10-15 items with dichotomy response, yes or not.

Each station had different items which assessed several competencies. The percentage value of each competency was $25 \%$ of clinics, $20 \%$ of techniques, $30 \%$ of management of Pharmacy Services, $20 \%$ of communication and $5 \%$ of educational and preventive skills.

\section{Study design}

Verbal instructions on the OSCE procedure and content were provided to the students and their participation was voluntary. The participants were assigned randomized to groups of 5 people who worked, consequently, through the same circuit of five stations, on different days the Bachelor and Master students. Portable walls indicating the number of each station were placed between the stations. An alarm indicating the beginning and the termination of each examination session was coupled to all stations. Each examination session lasted for 8 min per station plus $1 \mathrm{~min}$ to move to the following station. Another minute was given to students to read the instructions of the station. The whole round lasted for $50 \mathrm{~min}$. There were three versions of the case of each station. 
Five examiners observed the stations (three simulated patient and two written stations). Three actresses were trained to act as standardized simulated patients.

\section{Students' opinion}

A questionnaire was therefore developed ad hoc for this study, it included statements and open-ended questions. A five point Likert-type scale ('Strongly Disagree' to 'Strongly Agree') was used by the participants to score their agreement with the OSCE, in addition, they completed open-ended questions focused on the 'strengths' of the OSCE and areas they would 'like to be improved'.

\section{Statistical methods}

Data were analyzed by calculating means and standard deviations or median and percentiles, according to a normal distribution or not, respectively, for numerical variables and absolute and relative frequencies were used for the qualitative ones. To study the possible differences, the $\mathrm{t}$-student test or ANOVA was compared for quantitative variables and for qualitative variables the Chi-square test corrected by Fisher. Statistically significant values were assumed $p<0.05$. The Cronbach's $\alpha$ coefficient was used to evaluate the internal consistency of the survey. A Cronbach's alpha value of $0.50-0.69$ is acceptable, while values of $0.70-0.90$ indicate a strong internal consistency. ${ }^{20}$ The analyses were performed using SPSS software for windows, version 19.0 (IBM Corporation, Armonk, NY, USA).

\section{RESULTS}

The results of this study are based on data from 47 students (33 from Bachelor and 14 from Master, representing $15.6 \%$ and $58.3 \%$ of the entire class, respectively). There were $68.1 \% \quad(32 / 47)$ female respondents. The majority $(70.2 \%, 33 / 47)$ of the respondents were within the age group of 20-24 years (21.11 \pm 4.16$)$. About $61.7 \%$ (29/47) reported that they attended of the $75-100 \%$ of the PC classes (Table 1).

The internal reliability of the assessment as measured by Cronbach's alpha was 0.730 , considered strong.

The mean score of the global OSCE was $65.17 \pm 11.30$ out of 100 points (min. 44, max. 83), being higher for the Master student $(68.79 \pm 12.27)$ than Bachelor (63.64 \pm 10.69$)$ as expected. Statistically significant differences were observed in the "Dispensing" station in Bachelor and Master Students $(p=0.008$; $76.67 \pm 12.10$ vs $87.14 \pm 11.22$, respectively), particularly in communication competency ( $p=0.00618 .18 \pm 7.69$ vs $25 \pm 6.50$ ) (Table 2). When the results were broken down by the station, it was observed (Table 2): 79.79 \pm 12.68

\begin{tabular}{|c|c|c|c|}
\hline \multicolumn{4}{|c|}{ Table 1: Demographic data. } \\
\hline & Bachelor & Master & Total \\
\hline Age & & & \\
\hline Mean & 22.7 & 27.5 & 24.1 \\
\hline SD & 3.2 & 4.3 & 4.2 \\
\hline Gender & & & \\
\hline Female & 23 & 9 & 32 \\
\hline$\%$ & 64 & 70 & 68 \\
\hline Attendance to class \\
(75-100\%) & & & \\
\hline$N$ & 16 & 13 & 29 \\
\hline$\%$ & 48 & 93 & 62 \\
\hline
\end{tabular}

\begin{tabular}{|c|c|c|c|c|}
\hline & Bachelor & Master & Total & $P$ \\
\hline \multicolumn{5}{|c|}{ Dispensing Station } \\
\hline Mean & 76.67 & 87.14 & 79.79 & 0.008 \\
\hline $\mathrm{N}$ & 33 & 14 & 47 & \\
\hline SD & 12.1 & 11.22 & 12.68 & \\
\hline Median & 80 & 87.5 & 80 & \\
\hline Error & 2.11 & 3 & 1.85 & \\
\hline Min & 35 & 60 & 35 & \\
\hline Max & 95 & 100 & 100 & \\
\hline \multicolumn{5}{|c|}{$\begin{array}{c}\text { Dispensing Record } \\
\text { Station }\end{array}$} \\
\hline Mean & 46.67 & 46.43 & 46.60 & 0.97 \\
\hline $\mathrm{N}$ & 33 & 14 & 47 & \\
\hline SD & 19.79 & 20.61 & 19.81 & \\
\hline Median & 50 & 50 & 50 & \\
\hline Error & 3.45 & 5.51 & 2.89 & \\
\hline Min & 10 & 10 & 10 & \\
\hline Max & 100 & 70 & 100 & \\
\hline \multicolumn{5}{|c|}{$\begin{array}{l}\text { Minor Ailments } \\
\text { Station }\end{array}$} \\
\hline Mean & 63.48 & 66.79 & 64.47 & 0.535 \\
\hline $\mathrm{N}$ & 33 & 14 & 47 & \\
\hline SD & 16.42 & 16.83 & 16.43 & \\
\hline Median & 65 & 70 & 70 & \\
\hline Error & 2.86 & 4.50 & 2.4 & \\
\hline Min & 15 & 35 & 15 & \\
\hline Max & 90 & 90 & 90 & \\
\hline \multicolumn{5}{|c|}{$\begin{array}{c}\text { Medication Review } \\
\text { with Follow-up Station }\end{array}$} \\
\hline Mean & 46.67 & 52.14 & 48.30 & 0.415 \\
\hline $\mathrm{N}$ & 33 & 14 & 47 & \\
\hline SD & 22.59 & 15.78 & 20.78 & \\
\hline
\end{tabular}




\begin{tabular}{|c|c|c|c|c|}
\hline \multicolumn{5}{|c|}{ Table 2: Cont'd } \\
\hline Median & 40 & 50 & 50 & \\
\hline Error & 3.93 & 4.26 & 3.03 & \\
\hline Min & 0 & 10 & 0 & \\
\hline Max & 100 & 70 & 100 & \\
\hline \multicolumn{5}{|c|}{ Adherence Station } \\
\hline Mean & 84.70 & 91.43 & 86.70 & 0.200 \\
\hline $\mathrm{N}$ & 33 & 14 & 47 & \\
\hline SD & 17.50 & 12.62 & 16.36 & \\
\hline Median & 90 & 95 & 90 & \\
\hline Error & 3.05 & 3.37 & 2.39 & \\
\hline Min & 35 & 55 & 35 & \\
\hline Max & 100 & 100 & 100 & \\
\hline \multicolumn{5}{|c|}{ Total OSCE } \\
\hline Mean & 63.64 & 68.79 & 65.17 & 0.155 \\
\hline $\mathrm{N}$ & 33 & 14 & 47 & \\
\hline SD & 10.69 & 12.27 & 11.30 & \\
\hline Median & 64 & 73 & 68 & \\
\hline Min & 44 & 47 & 44 & \\
\hline Max & 83 & 83 & 83 & \\
\hline
\end{tabular}

score out of 100 (min.35, max.100) was the mean reached in the "Dispensing" station. Technique competency was the best scored ( $28.30 \pm 5.24$ out of 30$)$.

Students in the "Dispensing Record" station obtained $48.3 \pm 20.78$ out of 100 (min.10, max. 100). Technique competency was the best scored $(31.49 \pm 11.42$ out of 50).

In the "Minor Ailments" station students scored

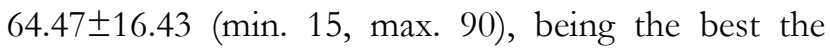
competency pharmacy services $(35.00 \pm 6.50$ out of 40$)$. The "Medication Review with Follow-up" (MRF) station was scored with $46.6 \pm 19.81$ out of 100 (min.0, max.100). The best competency was the technique (15.32 \pm 8.56 out of 20$)$.

Finally, "Adherence" station had the major percentage with the highest score (100) in the $31.9 \%$ (86.7 \pm 16.36 ; min.35, max.100). The best competency was communication (32.87 \pm 5.39 out of 35 ) (Table 2 ).

If we paid attention to the specific items, conservation item in the "Dispensing Record" station was better scored $(p=0.036)$ for Bachelor students $(9.39 \pm 2.42)$ than from Master (7.14 \pm 4.69$)$; the item about detecting medication related problem in the "MRF" station was

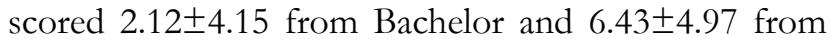
Master ( $p=0.004)$. And finally, we observed statistically significant differences in the item of Morisky-Green test in the "Adherence" station $(3.48 \pm 2.33$ vs $5.00 \pm 0.00$, $p=0.020)$.

When we analyzed competencies (Table 2), we observed statistically significant differences between Bachelor and Master in pharmacy services $(p=0.014 ; 18.87 \pm 3.53$ vs $21.71 \pm 3.34$ out of 30$)$. The best competency was techniques (15.02 \pm 3.06 out of 20) (Table 3).

The number of students who passed the exam was $85.10 \% \quad(n=27 ; 81.82 \%$ from Bachelor and $n=13$; $92.86 \%$ from Master). If a $95 \%$ confidence interval was established in 6.5 , the percentage of passing students was $55.32 \% \quad(n=26 ; 48.48 \% n=16$ from Bachelor and $71.43 \% n=10$ from Master). No statistically significant differences in the results between students who did the OSCE in the morning or in the afternoon were found $(p=0.180)$.

\section{Students Opinion Survey}

Cronbach's alpha showed an internal reliability of the survey of 0.769 . The global score had a mean of $4.50 \pm 0.50$ (51.1\% scored 5 and $48.9 \%$ scored 4$)$. In general, students from the Master scored all the items better than students from Bachelor (Table 4).

The worst item scored was "the degree of difficulty of the "Dispensing Record" station" (2.87 \pm 1.04$)$ and the highest was the "organization of the OSCE" (4.63 \pm 0.61$)$. On the other hand, the influence of the observers did not affect to the OSCE (2.97士1.10).

We found statistically significant differences when we analyzed the teaching class (Bachelor vs Master) in several items: "The OSCE corresponds to the training

\begin{tabular}{|c|c|c|c|c|}
\hline \multicolumn{7}{|c|}{ Table 3: Scores of competencies. } \\
\hline Competencies & Bachelor & Master & Total & $\boldsymbol{p}$ \\
\hline Clinics & $13.42 \pm 3.95$ & $14.43 \pm 4.93$ & $13.72 \pm 4.23$ & 0.463 \\
\hline $\begin{array}{c}\text { Pharmacy } \\
\text { Services }\end{array}$ & $18.88 \pm 3.53$ & $21.71 \pm 3.34$ & $19.72 \pm 3.68$ & 0.014 \\
\hline $\begin{array}{c}\text { Education and } \\
\text { Prevention }\end{array}$ & $4.36 \pm 2.85$ & $4.71 \pm 2.89$ & $4.47 \pm 2.38$ & 0.703 \\
\hline Techniques & $15.21 \pm 2.78$ & $14.57 \pm 3.72$ & $15.02 \pm 3.06$ & 0.518 \\
\hline Communication & $13.94 \pm 2.77$ & $15.71 \pm 3.39$ & $14.47 \pm 3.04$ & 0.067 \\
\hline
\end{tabular}


received in class in the subject" $(4.33 \pm 0.60$ vs $4.77 \pm 0.44$; $p=0.021)$, "the degree of difficulty of the "Minor Ailments" station" ( $3.61 \pm 0.70$ vs $4.14 \pm 0.77 ; p=0.025)$, "the degree of difficulty of the "Medication Review with Follow-up" station" ( $3.73 \pm 0.76$ vs $4.50 \pm 0.65 p=0.002$ ), "The OSCE better measures the competencies acquired with respect to test exams of the subject" $(3.87 \pm 1.11$ vs $4.69 \pm 0.63 ; p=0.016)$ and "The OSCE measures better the competencies acquired regarding the resolution of written practical cases of the subject" $(4.03 \pm 0.98$ vs $4.69 \pm 0.48 ; p=0.026$ ).

We found statistically significant differences in "the degree of difficulty of the "Dispensing Record" station" when we differentiated by age $(p=0.020)$ and
"The previous information received about the OSCE has been adequate" ( $p=0.038)$, "the degree of global difficulty" ( $p=0.006)$, "the degree of difficulty of the "Dispensing" station" ( $\phi=0.002)$ when we analyzed by attending classes (Table 4).

\section{DISCUSSION}

This innovative teaching-learning Project has been the first to carry out an OSCE about PC in Pharmacy students in Spain. We developed OSCE cases for scenarios that are found frequently in community pharmacies to evaluate how to provide professional advice to patients in a structured manner by pharmacy services.

Table 4: Questionnaire opinion about the OSCE.

\begin{tabular}{|c|c|c|c|c|c|c|c|c|c|}
\hline Item & Mean & SD & Median & 1 & 2 & 3 & 4 & 5 & $\begin{array}{l}\text { p Bachelor } \\
\text { vs Master }\end{array}$ \\
\hline $\begin{array}{l}\text { The OSCE corresponds to the training received } \\
\text { in class in the subject }\end{array}$ & 4.46 & 0.59 & 4.5 & $0(0)$ & $0(0)$ & $\begin{array}{l}4.3 \\
(2)\end{array}$ & $\begin{array}{l}44.7 \\
(21)\end{array}$ & $\begin{array}{l}48.9 \\
(23)\end{array}$ & 0.021 \\
\hline $\begin{array}{l}\text { The practices of the subject have helped you to } \\
\text { take the OSCE }\end{array}$ & 4.24 & 0.85 & 4 & $0(0)$ & $\begin{array}{l}2.1 \\
(1)\end{array}$ & $\begin{array}{c}17.0 \\
(8)\end{array}$ & $\begin{array}{l}27.7 \\
(13)\end{array}$ & $\begin{array}{l}42.6 \\
(20)\end{array}$ & 0.152 \\
\hline $\begin{array}{l}\text { The previous information received about the } \\
\text { OSCE has been adequate }\end{array}$ & 4.35 & 0.9 & 5 & $0(0)$ & $\begin{array}{l}4.3 \\
(2)\end{array}$ & $\begin{array}{c}14.9 \\
(7)\end{array}$ & $\begin{array}{l}21.3 \\
(10)\end{array}$ & $\begin{array}{l}57.4 \\
(27)\end{array}$ & 0.864 \\
\hline The organization of the OSCE & 4.64 & 0.57 & 5 & $0(0)$ & $0(0)$ & $\begin{array}{l}4.3 \\
(2)\end{array}$ & $\begin{array}{l}27.7 \\
(13)\end{array}$ & $\begin{array}{l}68.1 \\
(32)\end{array}$ & 0.085 \\
\hline The duration of the OSCE in global (50 $\mathrm{min}$ ) & 4 & 0.72 & 4 & $0(0)$ & $\begin{array}{l}2.1 \\
(1)\end{array}$ & $\begin{array}{c}19.1 \\
(9)\end{array}$ & $\begin{array}{l}55.3 \\
(26)\end{array}$ & $\begin{array}{l}23.4 \\
(11)\end{array}$ & 0.188 \\
\hline The duration of each OSCE station (8 $\mathrm{min}$ ) & 3.52 & 0.84 & 3 & $\begin{array}{l}2.1 \\
(1)\end{array}$ & $0(0)$ & $\begin{array}{l}55.3 \\
(26)\end{array}$ & $\begin{array}{l}25.5 \\
(12)\end{array}$ & $\begin{array}{c}14.9 \\
(7)\end{array}$ & 0.639 \\
\hline The degree of difficulty of the OSCE in global & 3.8 & 0.63 & 4 & $0(0)$ & $\begin{array}{l}2.1 \\
(1)\end{array}$ & $\begin{array}{l}23.4 \\
(11)\end{array}$ & $\begin{array}{l}61.7 \\
(29)\end{array}$ & $\begin{array}{l}8.5 \\
(4)\end{array}$ & 0.151 \\
\hline $\begin{array}{l}\text { a. } \\
\text { Station 1: Dispensing }\end{array}$ & 4 & 1 & 4 & $\begin{array}{l}2.1 \\
(1)\end{array}$ & $\begin{array}{l}8.5 \\
(4)\end{array}$ & $\begin{array}{c}10.6 \\
(5)\end{array}$ & $\begin{array}{l}44.7 \\
(21)\end{array}$ & $\begin{array}{l}34.0 \\
(16)\end{array}$ & 0.344 \\
\hline $\begin{array}{c}\mathrm{b} \text {. } \\
\text { Station 2: Dispensing record Analysis }\end{array}$ & 2.98 & 1.11 & 3 & $\begin{array}{c}10.6 \\
(5)\end{array}$ & $\begin{array}{c}19.1 \\
(9)\end{array}$ & $\begin{array}{l}42.6 \\
(20)\end{array}$ & $\begin{array}{c}17.0 \\
(8)\end{array}$ & $\begin{array}{c}10.6 \\
(5)\end{array}$ & 0.516 \\
\hline c. Station 3: Minor Ailments & 3.77 & 0.76 & 4 & $0(0)$ & $\begin{array}{l}2.1 \\
(1)\end{array}$ & $\begin{array}{l}36.2 \\
(17)\end{array}$ & $\begin{array}{l}44.7 \\
(21)\end{array}$ & $\begin{array}{c}17.0 \\
(8)\end{array}$ & 0.025 \\
\hline d. Station 4: Pharmacotherapeutic Station & 3.96 & 0.81 & 4 & $0(0)$ & $\begin{array}{l}2.1 \\
(1)\end{array}$ & $\begin{array}{l}27.7 \\
(13)\end{array}$ & $\begin{array}{l}42.6 \\
(20)\end{array}$ & $\begin{array}{l}27.7 \\
(13)\end{array}$ & 0.002 \\
\hline e. Station 5: Adherence & 4.19 & 0.8 & 4 & $0(0)$ & $\begin{array}{l}4.3 \\
(2)\end{array}$ & $\begin{array}{c}10.6 \\
(5)\end{array}$ & $\begin{array}{l}46.8 \\
(22)\end{array}$ & $\begin{array}{l}38.3 \\
(18)\end{array}$ & 0.084 \\
\hline $\begin{array}{l}\text { Understanding the tasks to be performed at the } \\
\text { stations }\end{array}$ & 4.13 & 78 & 4 & $0(0)$ & $\begin{array}{l}2.1 \\
(1)\end{array}$ & $\begin{array}{c}12.8 \\
(6)\end{array}$ & $\begin{array}{l}38.3 \\
(18)\end{array}$ & $\begin{array}{l}27.7 \\
(13)\end{array}$ & 0.38 \\
\hline $\begin{array}{l}\text { The presence of observers / actors has } \\
\text { influenced your performance }\end{array}$ & 3 & 1.2 & 3 & $\begin{array}{c}10.6 \\
(5)\end{array}$ & $\begin{array}{l}25.5 \\
(12)\end{array}$ & $\begin{array}{l}29.8 \\
(14)\end{array}$ & $\begin{array}{l}21.3 \\
(10)\end{array}$ & $\begin{array}{c}12.8 \\
(6)\end{array}$ & 0.793 \\
\hline $\begin{array}{l}\text { The cases raised are representative of the } \\
\text { actual practice }\end{array}$ & 4.49 & 0.59 & 5 & $0(0)$ & $0(0)$ & $\begin{array}{l}4.3 \\
(2)\end{array}$ & $\begin{array}{l}42.6 \\
(20)\end{array}$ & $\begin{array}{l}53.2 \\
(25)\end{array}$ & 0.537 \\
\hline $\begin{array}{c}\text { The OSCE better measures the competencies } \\
\text { acquired regarding test questions }\end{array}$ & 4.12 & 1.05 & 4 & $\begin{array}{l}4.3 \\
(2)\end{array}$ & $0(0)$ & $\begin{array}{c}19.1 \\
(9)\end{array}$ & $\begin{array}{l}25.5 \\
(12)\end{array}$ & $\begin{array}{l}42.6 \\
(20)\end{array}$ & 0.016 \\
\hline $\begin{array}{c}\text { The OSCE better measures the competencies } \\
\text { acquired regarding resolution of written case } \\
\text { studies }\end{array}$ & 4.22 & 0.92 & 4 & $\begin{array}{l}2.1 \\
(1)\end{array}$ & $\begin{array}{l}2.1 \\
(1)\end{array}$ & $\begin{array}{c}12.8 \\
(6)\end{array}$ & $\begin{array}{l}36.2 \\
(17)\end{array}$ & $\begin{array}{l}44.7 \\
(21)\end{array}$ & 0.026 \\
\hline Overall assessment of the OSCE in global & 4.51 & 0.51 & 5 & $0(0)$ & $0(0)$ & $0(0)$ & $\begin{array}{l}48.9 \\
(23)\end{array}$ & $\begin{array}{l}51.1 \\
(24)\end{array}$ & 0.926 \\
\hline
\end{tabular}


PC is an area of the Pharmacy in which the pharmacist participates actively in patient care, actively collaborating with other professionals and with the patient, in order to obtain a beneficial effect on the quality of life of the patient. ${ }^{21}$ These activities, carried out in different areas, are specified in the provision of pharmacy services, which are experiencing a considerable evolution in the community pharmacy environment. ${ }^{22}$ But nevertheless, in pharmaceutical educational terms, 20 years after the publication of the Dader Method as a benchmark in $\mathrm{PC}^{23}$ it continues to be observed that the actual provision of Professional Pharmacy Services among pharmacists is lower than it would be expected.

The change into professional practice in pharmacy in Spain is necessary to be expressed in the teaching base, in undergraduate and postgraduate training. Under this premise, it appears among the teaching community a high concern for the lack of real translation between training and practice in pharmacy services. It is known that the provision of Professional Pharmacy Services is a professional practice that requires the acquisition of specific knowledge, skills and attitudes in the pharmacist. OSCEs can assess clinical competencies and communication skills among professionals or students. ${ }^{24}$ Implementation of OSCEs may be an effective tool for assessment of the Center for the Advancement of Pharmacy Education domains. ${ }^{25}$ This tool assesses the third level of the Miller's pyramid in which students show how they perform these skills among others. ${ }^{26} \mathrm{It}$ is a good framework to standardized student-patient interaction.

We found some noteworthy data in various stations. For example, the best competency scored was technique in three of the five stations. There are a large number of studies in cognitive psychology that shows that general population acquire better understanding by undertaking actions and thinking about the repercussion of their actions that watching or listening to someone who tells them what that they must learn. ${ }^{27,28}$ In addition, among other advantages, experimentation forces students to become involved in learning becoming an essential part of the learning of the majority of the professional scientific and technical branches. ${ }^{29}$

The worst scored stations were the written station, "Dispensing record" and "MRF", not only by the score obtained but also by the assessment in the student questionnaire. However, in other medical OSCEs, "record" stations used to obtain worst scores. ${ }^{30}$ Nevertheless, according to the questionnaire, the low score in the "Dispensing record" station could be because it required more time. "MRF" station was trimmed to adapt to the time station, but in this case, the checklist was too short, so that if the student failed an item, the final value of the station was significantly reduced.

The significant differences in the "Dispensing record" station between Bachelor and Master, leads us to think that the vision of this service becomes more complete with the professional postgraduate profile. However, similar scores were observed from other services. Age also helps in the degree of difficulty of the "Dispensing Record" station. This can be explained by the fact that in the fifth year or in the Master they have practiced in the pharmacy or worked in one.

Class attendance helps the degree of difficulty of the test and especially of the dispensation, Master's students tended to attend more to classes, so they scored better. In the same way, Master's students score better on the questionnaire that the OSCE corresponds to what is seen in class, rather than Bachelor, especially the "Minor Ailments" and "MRF" services.

To our knowledge this is the first worldwide study of an OSCE conducted in PC. The same that other OSCEs are being introduced in several Faculties of Medicine, ${ }^{31-33}$ we believe that this OSCE could be performed in the Faculty of Pharmacy as final examination of Pharmaceutical Care. We acknowledge some limitations. Time station and to keep the same criteria with all students are technical aspects to improve in the next phases of the process. After the success of the pilot, it is intended to be implemented as an evaluation method in successive courses.

\section{CONCLUSION}

Community pharmacists can boost their counseling skills and abilities needed to implement patient-centered interventions. The use of blended learning-teaching methods with OSCEs constitutes a new tool to evaluate these PC skills.

\section{ACKNOWLEDGEMENT}

The authors would like to thank students who participated in the OSCEs and the Faculty of Pharmacy (University of Granada).

\section{CONFLICT OF INTEREST}

The authors report no conflicts of interest.

\section{Funding}

This study was funded by the Quality, Innovation and Prospective Unit of the University of Granada, within the call of 2018-2020 FIDO Plan. 


\section{ABBREVIATIONS}

EHEA: European Higher Education Area; MRF: Medication Review with Follow-up; OSCE: Objective Structures Clinical Examination; PC: Pharmaceutical Care; SD: Standard Deviation.

\section{REFERENCES}

1. Allemann SS, Foppe MVJW, Botermann L, Berger K, Griese N, Hersberger K. Pharmaceutical care: The PCNE definition. International Journal of Clinical Pharmacy. 2014;36(3):544-55.

2. Tan E, Stewart K, Elliott M, George J. Pharmacist services provided in general practice clinics: A systematic review and metaanalysis. Research in Social and Administrative Pharmacy. 2014;10(4):608-22.

3. Vrijens B, DeGeest S, Hughes D, Przemyslaw K, Demonceau J, Ruppar T, et al. A new taxonomy for describing and defining adherence to medications. British Journal of Clinical Pharmacology. 2012;73(5):691-705.

4. Sáez-Benito L, Fernandez-Llimos F, Feletto E, Gastelurrutia MA, MartínezMartínez F, Benrimoj SI. Evidence of the clinical effectiveness of cognitive pharmaceutical services for aged patients. Age Ageing. 2013;42(4):442-9.

5. Hughes CM, Hawwa AF, Scullin C, Anderson C, Bernsten CB, Björnsdóttir $\mathrm{I}$, et al. Provision of pharmaceutical care by community pharmacists: A comparison across Europe. Pharmacy World and Science. 2010;32(4):47287.

6. Berger K, Griese N. Pharmaceutical counselling: the patient in the centre. Pharmazie in Unserer Zei. 2012;276-82.

7. Salinas J. Innovación docente y uso de las TIC en la enseñanza universitaria. Revista de Universidad y Sociedad del Conocimiento (RUSC). Universities and Knowledge Society. 2004;1.

8. Ahmed A, Mohamad HN, Qais AMA. Perception of pharmacy students in Malaysia on the use of objective structured clinical examinations to evaluate competencie. American Journal of Pharmaceutical Education. 2007;71(6):118

9. Austin Z, Croteau D, Marini A, Violato C. Continuous professional development: The Ontario experience in professional self-regulation through quality assurance and per-review. American Journal of Pharmaceutical Education. 2003;67(2):225

10. Harden RM, Stevenson M, Downie WW, Wilson GM. Assessment of clinical competencie using objective structured examination. British Medical Journal. 1975;1(5955):1447-51

11. Khan KZ, Ramachandran S, Gaunt K, Pushkar P. The Objective Structured Clinical Examination (OSCE): AMEE Guide No. 81. Part I: An historical and theoretical perspective. Medical Teacher. 2013;35(9):e1437-46.

12. Pebc.ca. Internet. Toronto: The Pharmacy Examining Board of Canada. 2017. http://www. pebc.ca.

13. Austin Z, O'Byrne CC, Pugsley J, Munoz LQ. Development and validation processes for an objective structured clinical examination (OSCE) for entryto-practice certification in pharmacy: The Canadian experience. American Journal of Pharmaceutical Education. 2003;67(3):76.

14. Bartfay WJ, Rombough R, Howse E, Leblanc R. Evaluation. The OSCE approach in nursing education. The Canadian Nurse. 2004;100(3):18-23.

15. Mitchell MI, Henderson A, Groves M, Dalton M, Nulty D. The objective structured clinical examination (OSCE): Optimizing its value in the undergraduate nursing curriculum. Nurse Education Today. 2009;29(4):398404.

16. Mitchel MI, Jeffrey C. An implementation Framework for the OSCE "Best Practice Guidelines" Designed to improve nurse preparedness for practice. Office for learning and teaching, Australian Government, Sydney. 2013.
17. Rushforth HE. Objective structured clinical examination (OSCE): Review of literature and implications for nursing education. Nurse Education Today. 2007;27(5):481-90.

18. Walsh M, Bailey P, Koren I. Objective structured clinical evaluation of clinical competencie: An integrative review. Journal of Advanced Nursing. 2009;6(8):1584-95.

19. Muldoon K, Biesty L, Smith V. 'I found the OSCE very stressful': Student midwives' attitudes towards an objective structured clinical examination (OSCE). Nurse Education Today. 2014;34(3):468-73.

20. Cronbach L, Shavelson RJ. My current thoughts on coefficient alpha and successor procedures. Educational and Psychological Measurement. 2004;64(3):391-418.

21. Faus MJ, Amariles P, Martínez-Martínez F. Atención Farmacéutica. Servicios farmacéuticos orientados al Paciente. Editorial Editorial Fleming y Técnica Avican. 2018.

22. Marinkovic V, Stojkovic T, Zekovic M, Tasic L, Krajnovic D. Community Pharmacists' Attitudes and Professional Practice in Relation to the Patient Safety Incidents. Indian Journal of Pharmaceutical Education and Research. 2020;54(4):194-205.

23. Sabater D, Silva MM, Faus MJ. Dader Method: Medication Review Followup Guide. 2007. http://www.ugr.es/ cts131/esp/guias/GUIA\%20FINAL\%20 DADER.pdf.

24. Jefferies A, Simmons B, Tabak D, Mcllroy JH, Lee KS, Roukema H, et al. Using an objective structured clinical examination (OSCE) to assess multiple physician competencies in postgraduate training. Medical Teacher. 2007;29(2-3):183-91.

25. Urteaga EM, Attridge RL, Tovar JM, Witte AP. Evaluation of Clinical and Communication Skills of Pharmacy Students and Pharmacists with an Objective Structured Clinical Examination. American Journal of Pharmaceutical Education. 2015;79(8):122.

26. Williams BW, Byrne PD, Welindt D, Williams MV. Miller's Pyramid and Core Competency Assessment: A Study in Relationship Construct Validity. Journal of Continuing Education in the Health Professions. 2016;36(4)295-9.

27. Dormido S. Control Learning: Present and Future. Annual Reviews in Control. 2004;28(1):115-36.

28. Mai CW, Lee EL, Wong PS, Er HM. Evaluation of Computer-based Simulation Learning on Knowledge, Learning Approaches and Motivation among Pharmacy Students. Indian Journal of Pharmaceutical Education and Research. 2019;53(4):595-602.

29. Calvo I, Zulueta E, Gangoiti U, López JM. Laboratorios remotos y virtuales en enseñanzas técnicas y científicas. e-Revista de didáctica. 1988;5911(3):1-21.

30. Ramos JM, Martínez-Mayoral MA, Sánchez-Ferrer F, Morales J, Sempere T, Belinchón I, Compañ AF. Análisis de la prueba de evaluación clínica objetiva estructurada (ECOE) de sexto curso en la Facultad de Medicina de la Universidad Miguel Hernández de Elche. Educación Médica. 2019;20(S1):2936 .

31. Daniels VJ, Harley D. The effect on reliability and sensitivity to level of training of combining analytic and holistic rating scales for assessing communication skills in an internal medicine resident OSCE. Patient Education and Counseling. 2007;100(7):1382-6.

32. Setyonugroho W, Kropmans T, Murphy R, Hayes P, Dalen JV, Kennedy KM True communication skills assessment in interdepartmental OSCE stations: Standard setting using the MAAS-Global and Edu G. Patient Education and Counseling. 2018;101(1):147-51.

33. Wang CY, Chen JD, Wang CH, Wang JY, Tai CJ, Hsieh TY, et al. Effects of Job Burnout and Emotional Labor on Objective Structured Clinical Examination Performance Among Interns and Residents in Taiwan. Evaluation and Health Professions. 2019;42(2):233-57. 


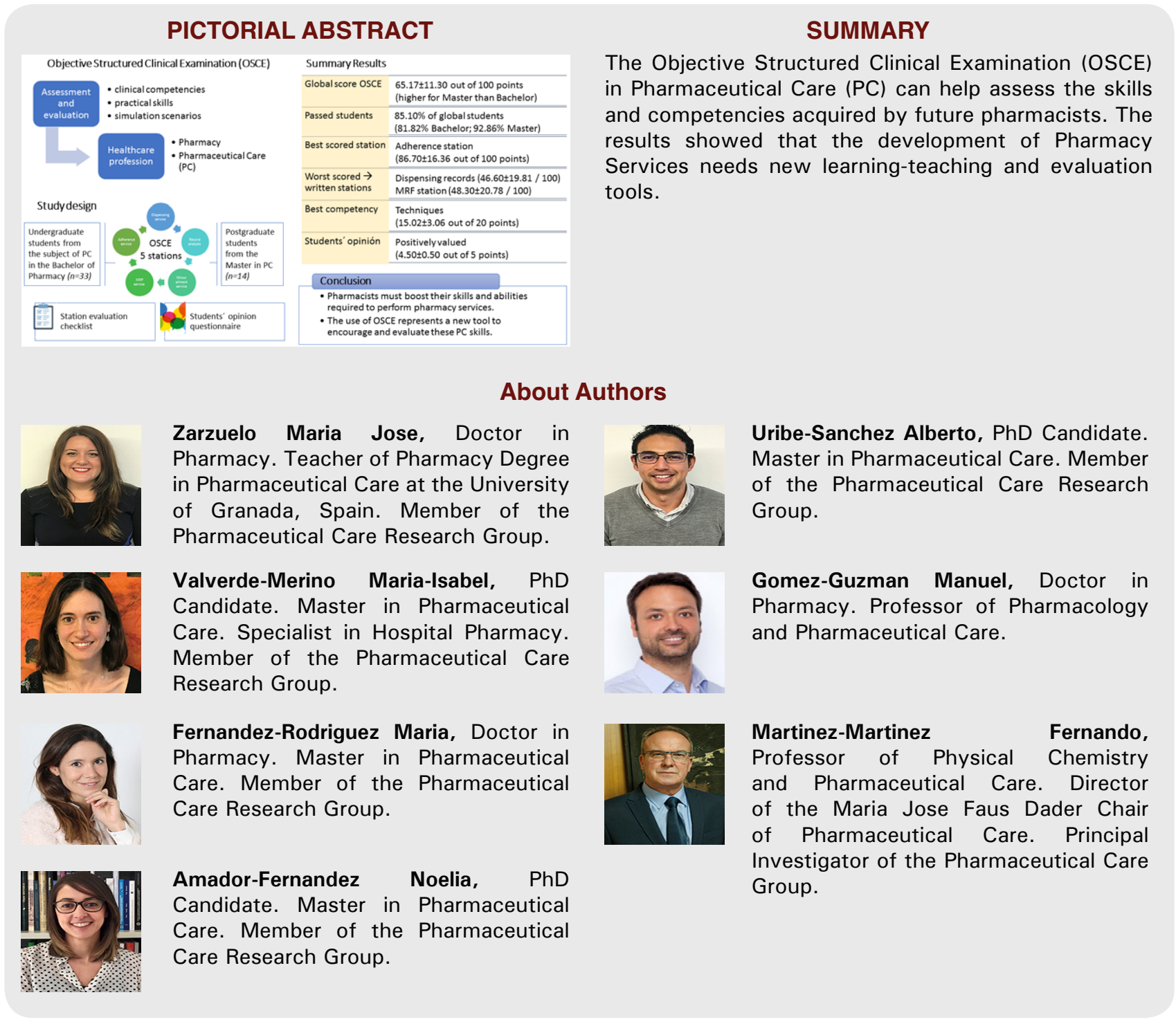

Cite this article: Zarzuelo MJ, Valverde-Merino MI, Fernandez-Rodriguez M, Amador-Fernandez N, UribeSanchez A, Gomez-Guzman M, et al. Results of Development and Application of an Objective Structured Clinical Examination: A Pioneering Experience in Pharmaceutical Care. Indian J of Pharmaceutical Education and Research. $2021 ; 55(2): 621-8$. 